\title{
SISTEM PENGAWASAN DAN PENGADUAN PEMASANGAN REKLAME DENGAN TEKNOLOGI MOBILE
}

\author{
Gunawan $^{1}$, Asep Indra Syahyadi ${ }^{2}$ \\ ${ }^{1}$ Program Studi Sistem Informasi, UIN Alauddin Makassar, Makassar \\ ${ }^{2}$ Program Studi Teknik Informatika, UIN Alauddin Makassar, Makassar \\ e-mail: ${ }^{1}$ gunawan@uin-alauddin.ac.id, ${ }^{2}$ asep@uin-alauddin.ac.id
}

\begin{abstract}
Abstrak
Penelitian ini bertujuan untuk merancang sebuah aplikasi Sistem Pengawasan Dan Pengaduan Pemasangan Reklame Dengan Teknologi Mobile dimana teknologi mobile yang digunakan adalah sistem android. Sistem ini dapat memberikan informasi penempatan titik-titik penyebaran reklame dan pengenalan informasi reklame dengan QR Code secara otomatis menggunakan android smartphone. Metode yang digunakan adalah metode eksperimental dan studi literatur. Layanan ini dibagi menjadi dua bagian yaitu aplikasi android dan aplikasi server (website). Pengujian dilakukan dengan menguji fungsionalitas sistem seperti informasi detail reklame, laporan-laporan tentang pelanggaran reklame, menampilkan data-data reklame. Sistem yang dibangun dirancang menggunakan UML (Unified Modeling Language). Penelitian ini menghasilkan sebuah aplikasi PHP dan MYSQL dengan user admin, petugas dan pimpinan dimana sistem ini mampu membantu proses membantu petugas dalam melakukan monitoring terhadap reklame yang terpasang. Dengan adanya sistem ini, diharapkan dapat membantu pimpinan untuk melihat laporan pelanggaran yang telah dilaporkan oleh petugas.
\end{abstract}

Kata kunci : Android; QRCode; Reklame; UML (Unified Modeling Language)

\begin{abstract}
This study aims to design an application for the Monitoring and Complaint System for Advertising with Mobile Technology, where the mobile technology used is the Android system. This system can provide information on the placement of billboard distribution points and the introduction of billboard information with QR Code automatically using an android smartphone. The method used is the experimental method and literature study. This service is divided into two parts, namely the android application and the server application (website). Testing is done by testing the functionality of the system such as detailed information on billboards, reports on billboard violations, displaying billboard data. The system built is designed using UML (Unified Modeling Language). This study produces a PHP and MYSQL application with admin users, officers, and leaders where this system can assist the process of assisting officers in monitoring the advertisements installed. With this system, it is hoped that it can help the leadership to see reports of violations that have been reported by officers.
\end{abstract}

Keywords : Android; QRCode; Advertisement; UML (Unified Modeling Language) 


\section{PENDAHULUAN}

Pertumbuhan reklame di kota-kota besar mengalami perkembangan pesat yang membuat persaingan maupun kompetisi usaha yang mengharuskan setiap perusahaan atau individu untuk bisa bersaing dalam hal menarik perhatian setiap konsumen sehingga untuk dapat menarik konsumen dapat melalui publikasi dengan pemasangan reklame.

Reklame menjadi salah satu sumber pendapatan pajak di suatu daerah. Hampir di setiap daerah memiliki Perda yang mengatur tentang pemasangan reklame yang mana pemasangan reklame harus melalui proses perizinan dan setiap izin reklame memiliki masa berlaku penayangan. Penyebaran reklame yang sangat banyak akan membutuhkan pengawasan terhadap reklame yang tidak mempunyai izin dan reklame yang tidak sesuai dengan aturan pemasangan reklame. Salah satunya Kota Makassar yang memiliki reklame yang tersebar di dalam kota.

Media cetak dan elektronik, menjadi peluang besar bagi para pengguna dibidang perdagangan, dimana yang sangat diminati adalah unit atau bagian pemasaran menggunakan tempat reklame dan masih dapat menarik calon konsumen dengan kemudahan diakses oleh semua pihak. Reklame masih menjadi alternatif untuk menjadi perhatian oleh pemerintah kota (Pemkot), sehingga untuk membuat kebijakan maupun peraturan serta tarif atau biaya penggunaan reklame berdasarkan peraturan daerah maupun undang-undang yang berlaku sehingga diharapkan mampu mengoptimalkan objek pajak reklame untuk menambah pemasukan atau pendapatan asli daerah (PAD).

Menjadi sumber penerimaan atau pemasukan yang mampu memberi kontribusi tersendiri bagi PAD kota Makassar, melalui pemerintah diharapkan dapat memaksimalkan salah satu potensi pajak pendapatan reklame. Namun kondisi penerapan di Kota Makassar belum sesuai apa yang di harapkan. Berdasarkan laporan Ketua Asosiasi Pengusaha Reklame Indonesia (ASPRI) "masih terdapat banyak pelanggaran pemasangan reklame yang harus ditertibkan, begitu juga dengan potensi penerimaan pajak baru harus lebih dioptimalkan". Pemerintah kota dalam hal ini Dinas Pendapatan Kota Makassar belum mengoptimalkan potensi pajak reklame di kota Makassar berdasarkan peraturan yang berlaku.

Dalam peraturan walikota makassar pemerintah telah meminta dispenda, tim penertiban dan penataan reklame untuk menertibkan pembangunan reklame video tron, bando, billboard, baliho dan neon box yang tidak memiliki izin. Informasi reklame yang terdaftar dapat diperoleh didispenda sedangkan reklame yang tidak memiliki izin hanya dapat diketahui dengan penelusuran langsung di lapangan dengan melakukan pencocokan data secara manual, sehingga memerlukan waktu yang cukup relative lama dalam pelayanan. Selain itu diperlukan pengawasan terhadap reklame yang menyalahi aturan dan memiliki izin yang tidak berlaku. Untuk membantu mengatasi masalah ini, dapat dilakukan dengan membuat suatu aplikasi yang memudahkan dalam mengawasi dan mengidentifikasi reklame yang menyalahi aturan.

Tren perkembangan teknologi dan infomasi membuat pola pikir dan interaksi pengguna terhadap sistem pengawasan dan pengaduan pemasangan reklame. Pemanfaatan pada perkembgangan bidang teknologi akan membantu dalam menyelesaikan aktivitas pekerjaan pengguna secara sistem pengawasan dan pengaduan pemasangan reklame. Salah satu contoh pengolahan informasi menggunakan Android yaitu aplikasi atau program yang menerapkan aplikasi Android smartphone. Perangkat ini nantinya dapat digunakan oleh 
masyarakat luas sehingga penertiban reklame dapat melibatkan masyarakat dalam hal pengawasan dan pelaporan reklame yang menyalahi aturan. Perangkat ini akan bekerja dengan mendeteksi QR Code yang akan dipasang di reklame dan menampilkan informasi detail tentang reklame dan letak geografis reklame tersebut.

Seiring dengan perkembangan teknologi, smartphone android hadir menawarkan fleksibilitas serta harga terjangkau serta dapat dikembangkan secara massal karena bersifat Open Source. Dengan adanya suatu sistem pengenalan dan pelaporan informasi reklame tentunya akan mempermudah dalam mengidentifikasi reklame yang menyalahi aturan dan juga memudahkan petugas dalam melakukan pelaporan terhadap reklame- reklame yang menyalahi aturan.

Berdasarkan permasalahan tersebut, penelitian ini difokuskan untuk membangun sistem yang akan memudahkan dalam pengawasan pemasangan reklame dengan menyediakan informasi detail reklame dan menyediakan fitur pengaduan yang dapat digunakan oleh petugas dalam mengadukan informasi reklame yang melanggar aturan. Sistem yang dibangun menggunakan teknologi berbasis web [1]. Teknologi NodeJS, Ionic Framework dan Apache Cordova menyediakan layanan aplikasi berbasis mobile yang dapat diakses melalui aplikasi penjelajah dari komputer desktop ataupun aplikasi yang dapat dipasang dan dijalankan pada perangkat smartphone.

\section{TINJAUAN PUSTAKA}

\subsection{Reklame}

Penggunaan media reklame yang digunakan oleh individu (perorangan) maupun badan yang menyelenggarakan usaha bahkan perusahaan jasa periklanan yang menggunakan atas nama sendiri bahkan nama orang lain. Misalnya pelaksanaan kegiatan kampanye yang dilakukan oleh partai politik secara bersamaan, dimana dengan menggunakan media reklame untuk tujuan mempromosikan salah satu perserta atau contoh lainnya adalah penjualan produk yang sifatnya secara massal. Sesuai peraturan pemerintah dalam pelaksanaan pemasangan reklame sebagai berikut:

1) Pemilik jasa reklame atau produk merupakan perorangan (pribadi) maupun badan yang menyelenggarakan jasa tersebut untuk dan atas namanya sendiri.

2) Jasa Periklanan atau Biro Reklame dalam hal ini perusahaan yang merupakan badan yang bergerak yang di bidang jasa periklanan yang memenuhi persyaratan berdasarkan peraturan perundang-undangan yang berlaku.

Selain peraturan diatas, pemasangan reklame harus dapat memperhatikan estetika tata kota sehingga keselarasan antara luas bentuk maupun jenis pemasangan reklame untuk dapat menyesuaikan dengan kawasannya yang ada, kemudian atau lokasi tempat dimana reklame tersebut ditempatkan pada tempat yang seharusnya. Dalam hal pelaksanaannya, pemasangan reklame yang telah mendapatkan Ijin dan diperbolehkan oleh pemerintah yaitu reklame dalam bentuk media reklame dengan bahan kain (spanduk), materi reklame billboard (yang telah mendapatkan Ijin peletakan titik reklame), reklame kendaraan, vertikal banner, reklame udara, umbul-umbul, materi reklame large electronic display /megatron/ videotron (yang telah mendapatkan Ijin peletakan titik reklame) [2].

Menurut Marihot P. Siahaan [3] salah satu objek pajak reklame yaitu semua penyelenggara usaha reklame dapat dilakukan oleh penyelenggara reklame maupun perusahaan jasa periklanan yang terdaftar pada Dinas Pendapatan dan Pengelolaan Keuangan kabupaten/kota. 
Objek pajak reklame berlaku pada semua penyelenggara reklame yang dilakukan oleh perusahaan jasa periklanan.

Berdasarkan Peraturan Walikota Makassar Nomor 9 Tahun 2010 Makassar Objek Pajak Reklame terdiri dari 13 macam, meliputi: 1) Megatron, 2) Papan atau Billboard, 3) Berjalan, 4) Baliho, 5) Kain, 6) Selebaran 7) Melekat atau Stiker, 8) Film atau Slide, 9) Udara, 10) Apung, 11) Reklame Suara, 12) Peragaandan, dan 13) Reklame Insidentil

\subsection{Konsep Smart City Kota Makassar \\ Konsep pemerintah Kota Makassar} untuk dapat menjadi kota dunia yang nyaman bagi masyarakat, mengusung konsep melalui Program Smart City. Dengan mengadopsi budaya etnik lokal kota Makassar "Sombere" dalam arti keramahan dan membangun infrastruktur dari bidang teknologi namun, tidak melupakan budaya serta nilai-nilai lokal dari Masyarakat Makassar. Konsep Smart City ini mengedepankan pada layanan digital (system perangkat lunak berbasis web) dalam mendukung kegiatan pemerintah kota Makassar serta mengoptimalkan layanan pada masyarakat secara on-line sistem. Program tersebut sebagai berikut; 1) Apartemen Lorong, 2) Home Care, 3) Tangkasaki, 4) Free $39 \mathrm{Wi}-\mathrm{Fi}, 5)$ Lorong Garden, 6) CCTV Perkotaan, 7) Care and Rescue Center, dan 8) Smart Card.

Namun, smart city dalam pelaksanaan tidak sesuai dengan apa yang diidamkan. Ha ini bisa dilihat pada berita yang dilansir di media Tribunnews.com, yang menyebutkan bahwa "Solusinya lelang jabatan. Selama ini bukan banyaknya perda yang tak jalan, tapi karena human error. Menurut penelitian memang pemimpinnya yang tak bisa menegakkan perda," ucap Bapak Danny sebagai walikota Makassar, Rabu (8/10/2014). 8 (delapan) dari program tersebut menjelaskan bahwa minimnya pemahaman SKPD dalam mengimplementasikan kota cerdas membuat masyarakat tidak mampu berpartisipasi dalam mewujudkan konsep Smart City akibat kurang sosialisasi dari SKPD tersebut.

\subsection{QR Code (Quick Response Code)}

Kode QR merupakan jenis kode matriks atau kode batang dua dimensi yang dikembangkan oleh Denso. Pada prinsipnya QR Code dibuat sebagai suatu kode yang memungkinkan untuk dapat diterjemahkan dengan kecepatan tinggi [4].

Teknologi QR Code salah satu evolusi dari barcode (kode batang) dimana dari satu dimensi berkembang menjadi dua dimensi. Barcode hanya dapat menyimpan data informasi dengan metode horizontal, sedangkan QR Code dapat disematkan informasi baik secara horizontal maupun vertikal. QR Code berkapasitas tinggi dalam penyimpanan pengkodean data dan mampu menyimpan berbagai jenis data, seperti numerik, kanji, alphabetic, simbol, kana, hiragana, dan kode biner. Secara khusus, QR code dapat menyimpan data jenis numerik misalnya hingga 7.089 karakter, data alphanumeric 4.296 karakter, kode binari 2.844 byte, dan huruf kanji 1.817 karakter. Barcode menjadi sebuah simbol untuk penandaan objek nyata yang divisualisasikan dari pola batang-batang dengan berwarna hitam maupun putih dapat dengan mudah untuk dibaca oleh komputer [5]. Contoh sebuah QR Code dapat dilihat pada gambar berikut:

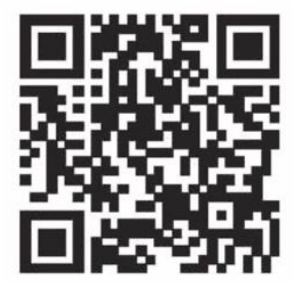

Gambar 1. Contoh QR Code 


\subsection{Penelitian Terdahulu}

Penelitian ini bukanlah hal yang baru, beberapa penelitian yang berkaitan dengan topik ini diantaranya Syahrul Mubarak (2017) mengenai Rancangan Bangun Sistem Perizinan Pemasangan Reklame Berbasis Web Berbasis Web" (Studi Kasus Kantor Pelayanan Terpadu Kabupaten Gowa) [6]. Penelitian ini mengembangkan sistem berbasis website menggunakan pemrograman PHP dan MySQL dengan metode waterfall dalam peracangan. Aplikasi ini mengelola dalam pembuatan perijinan dalam hal perpajakan yaitu pembayaran dan pembuatan laporan pendapatan pajak reklame.

Hilmi dan Setiyono (2013) dengan judul "Sistem Informasi Geografis Pengelolaan Reklame di Surabaya Berbasis Mobile"[7]. Penelitian ini mendeteksi lokasi reklame khususnya billboard produk maupun event pada sebuah instansi, dimana pada pelaksanaannya mengalami permasalahan terkait pemasangan reklame, contoh reklame tidak sah (illegal), reklame masa tayang yang habis (expire) menjadi faktor pengawasan yang kurang dalam sistem pengelolaan informasi reklame.

Fitri Andryastuti (2013) dengan judul "Mekanisme Pengelolaan Pengaduan Masyarakat atas pempasangan reklame di badan penanaman modal dan pelayanan perizinan di Kota Sukoharjo" [8], hasil pengamatan, prosedur pengelolaan pengaduan masyarakat atas pemasangan reklame terdiri atas: 1) penerimaan keluhan, 2) validasi atau verifikasi, 3) penelaahan dan klarifikasi oleh petugas melalui mekanisme proses penanganan awal dengan analisis masalah, serta tindak lanjut penyelesaian bersama unit kerja maupun instansi terkait.

Dari tinjauan pustaka di atas, maka peneliti mencoba melakukan penelitian untuk mengembangkan dan mengimplementsikan beberapa topik penelitian tersebut di Kota Makassar sehingga dapat mempermudah petugas dalam mengecek pemasangan reklame yang berpotensi menyalahi atau melanggar aturan.

\section{METODOLOGI PENELITIAN}

\subsection{Rancangan Penelitian}

Penelitian ini fokus dalam merancang aplikasi untuk perangkat mobile berbasis android yang digunakan oleh petugas dan warga dengan penyimpanan data secara online dimana hasil laporan dari petugas dan aduan dari warga yang berbasis web. Hasil/Output dari aplikasi adalah informasi reklame-reklame yang tersebar di Kota Makassar.

Penggunaan aplikasi terdiri dari 3 (tiga) jenis pengguna, yaitu pimpinan, admin, petugas lapangan atau warga untuk menyampaikan aduan.

\section{- Pimpinan}

Pimpinan/manajer memiliki fasilitas untuk mengetahui reklame- reklame yang tersebar dan mengetahui reklame-reklame yang menyalahi aturan berdasarkan laporan petugas lapangan dan aduan warga. Hasil yang ditampilkan adalah berupa laporan pelanggaran dan data reklame.

- Admin

Admin memiliki fasilitas untuk mengatur penggunaan user dari penggunaan aplikasi android.

\section{- Petugas Lapangan dan Warga}

Layanan untuk warga dan petugas di lapangan yang diberikan pada sistem ini adalah untuk mengetahui titik-titik reklame yang tersebar yang ditunjukkan langsung oleh sistem baik berupa informasi reklame yang sudah ada. Petugas lapangan dapat melakukan pelaporan pelanggaran dan warga juga dapat mengadukan pelanggaran reklame 
Metodologi penelitian ini menggunakan 5 (lima) tahapan, berikut tahapan penelitian yang dilakukan:

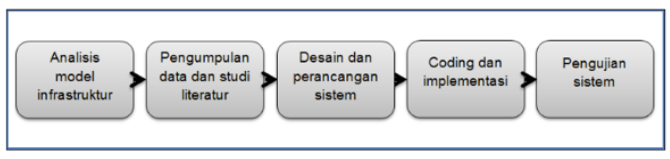

Gambar 1. Tahapan Penelitian

\subsection{Analisis Model Infrastruktur}

Pada fase ini, penelitian fokus pada upaya mengidentifikasi setiap masalah dan kompleksitasnya berdasarkan gambaran model nyata dan terjadi di lapangan. Tahap ini juga membahas mengenai teknologi yang akan digunakan seperti teknologi QR Code, arsitektur database dan jaringan

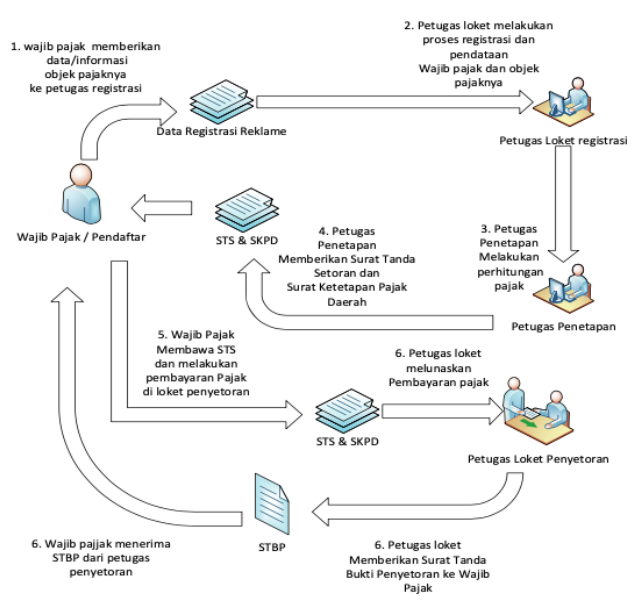

Gambar 2. Prosedur Pengurusan Izin Reklame [9]

\subsection{Pengumpulan Data dan Studi \\ Literatur}

Pada tahapan ini mengumpulkan data dan referensi tentang teknologi android yang berhubungan dengan Pembacaan QR Code, Google Maps untuk penyimpanan data.

\subsection{Desain Perancangan Sistem}

1) Use Case Diagram

Desain Sistem yang dibangun dirancang menggunakan UML (Unified Modeling Language) [10]. Rancangan terdiri dari beberapa tahap antara lain:
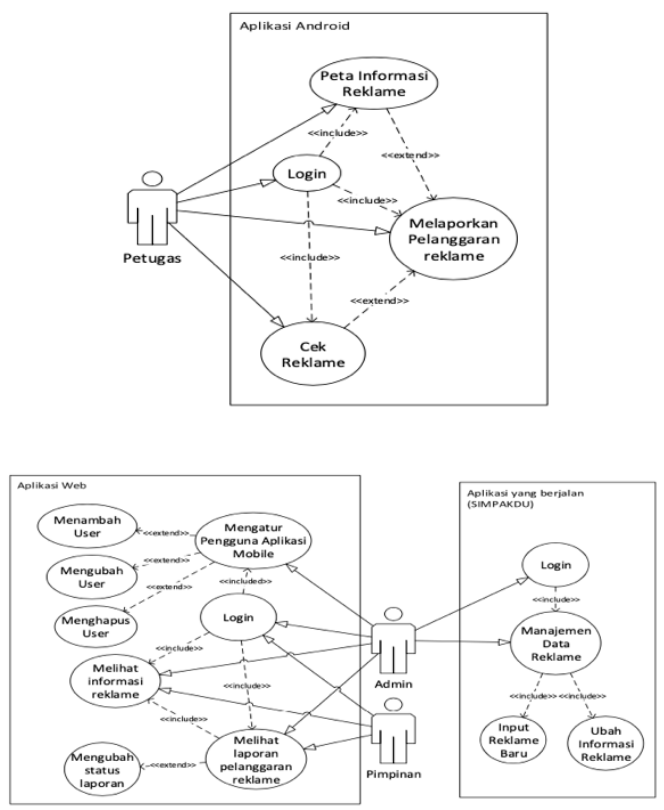

Gambar 3. Use Case Diagram

\section{2) Activity Diagram}

Activity diagram menggambarkan alur kerja (work flow) sebuah urutan aktivitas pada suatu proses. Berikut activity diagram pada pengguna (user) login:

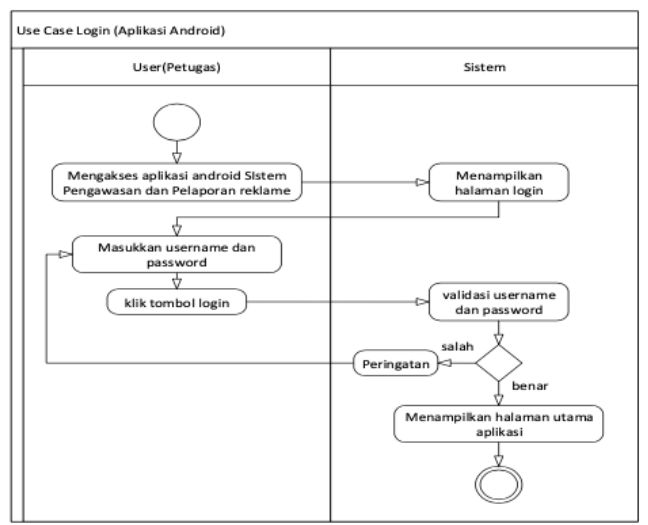

Gambar 4. Activity diagram dari use case $\operatorname{login}$ 
Pada gambar 4 diatas, aktifitas dari use case login yang dilakukan oleh user yakni petugas. Proses awal dalam melakukan login adalah user membuka aplikasi sistem pengawasan dan pengaduan pemasangan reklame berbasis android. Kemudian sistem akan menampilkan halaman login, setelah login tampil, user dapat memasukkan username dan password sesuai dengan data mereka masing-masing. Jika username dan password dimasukkan tidak sesuai, sistem akan menampilkan alert dan jika benar halaman home dari data mereka masingmasing akan ditampilkan oleh sistem.

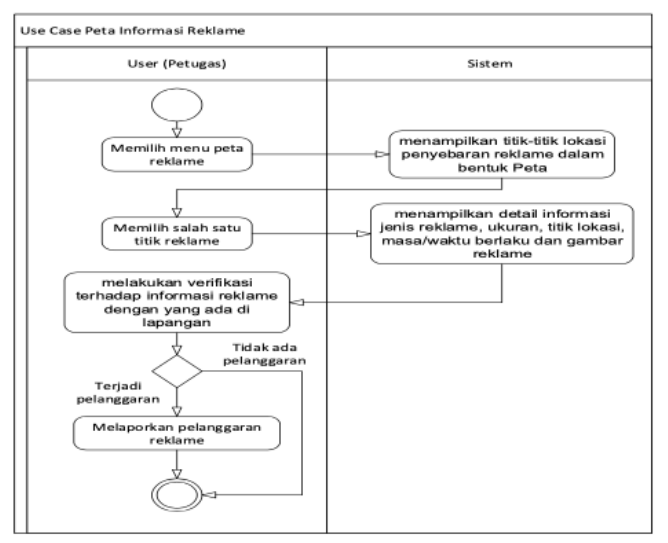

Gambar 5. Activity Diagram dari use case peta informasi reklame

Gambar 5 menjelaskan aktifitas dari use case peta informasi reklame yang dilakukan oleh user (petugas). Proses awal dari use case ini, user harus melakukan login terlebih dahulu, kemudian sistem akan menampilkan halaman home, lalu user memilih menu peta reklame, kemudian sistem akan menampilkan halaman titik-titik penyebaran reklame dalam bentuk peta, lalu user memilih salah satu titik reklame, kemudian sistem akan menampilkan detail informasi jenis reklame, ukuran, titik lokasi, masa/waktu berlaku dan gambar reklame. Jika data yang dimasukkan user terjadi pelanggaran atau tidak sesuai dengan sistem, maka sistem tidak akan menyimpan data tersebut, dan jika data tidak terjadi pelanggaran maka petugas dapat melaporkan memilih tombol laporkan.

\section{HASIL DAN PEMBAHASAN}

Hasil penelitian ini dikembangkan tiga aplikasi yang berjalan sesuai dengan layer dan arsitektur pada rancangan penelitian. Fungsi dan tampilan aplikasi tersebut adalah sebagai berikut:

1) Aplikasi Mobile (Android)
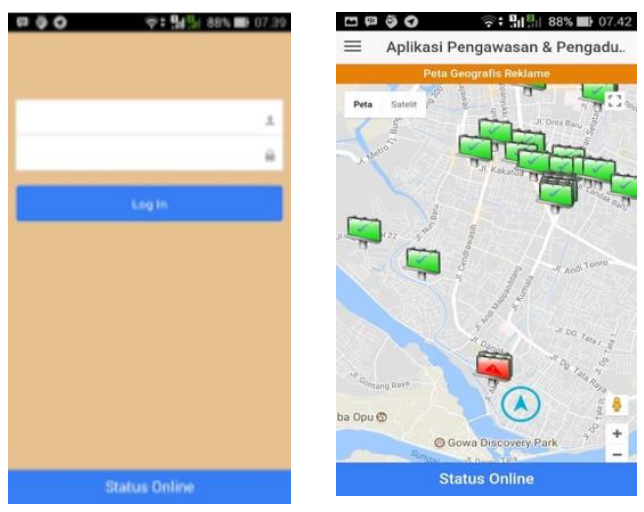

Gambar 1. Tampilan login dan Penyebaran Reklame
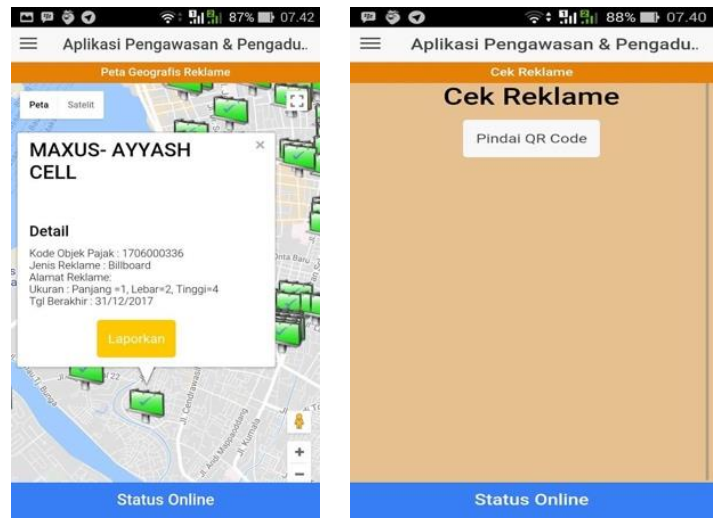

Gambar 2. Tampilan Lokasi dan Cek Reklame

Antar muka ini merupakan halaman yang berisi informasi penyebaran titik-titik lokasi reklame yang ditampilkan dalam bentuk peta. Setiap titik reklame berbentuk marker 
dengan memiliki penanda warna yang berbeda:

a. Warna hijau: Reklame yang dengan status normal

b. Warna kuning: Reklame yang memiliki izin berlaku belum diperpanjang

c. Warna Merah: Reklame yang melanggar dan sudah dilaporkan sebelumnya.

2) Aplikasi Website

- Laman Login

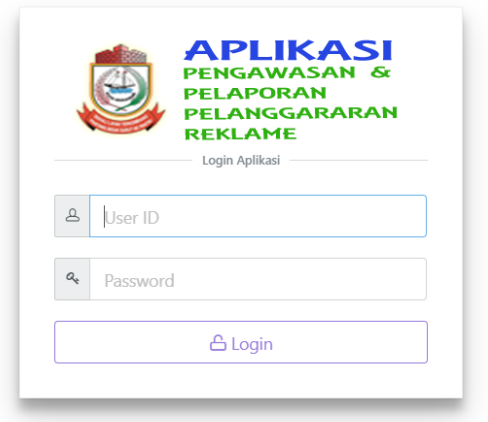

Gambar 3. Tampilan Login

- Laman Dashboard

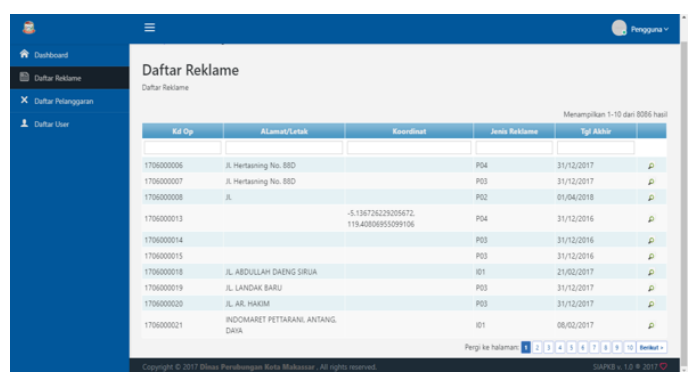

Gambar 4. Tampilan Daftar Reklame

3) Uji Kinerja dan Fitur Aplikasi Aturan penilaian dan pemberian skor dengan menggunakan pendekatan skala Likert pada penelitian ini adalah sebagai berikut:
Tabel 1. Persentasi Nilai

\begin{tabular}{|c|c|c|}
\hline No & Persepsi & Nilai \\
\hline 1 & $0 \%-24.99 \%$ & Kurang \\
\hline 2 & $25 \%-49.99 \%$ & Cukup \\
\hline 3 & $50 \%-74.99 \%$ & Baik \\
\hline 4 & $75 \%-100 \%$ & Sangat Baik \\
\hline
\end{tabular}

Berdasarkan data dari hasil kuesioner dari 20 responden, maka didapatkan nilai skor tertinggi adalah $4 \times 20=80$, dan skor terendah adalah $1 \times 20=20$. Selengkapnya mengenai data kuesioner akan disajikan pada tabel di bawah ini.

Tabel 2. Skor Jawaban Responden

\begin{tabular}{|c|c|c|c|c|c|c|c|c|c|}
\hline \multirow{2}{*}{$\begin{array}{l}\text { No } \\
\text { Responden }\end{array}$} & \multicolumn{9}{|c|}{ Nomor urut pertanyaan } \\
\hline & 1 & 2 & 3 & 4 & 5 & 6 & 7 & 8 & 9 \\
\hline R1 & 4 & 3 & 4 & 3 & 3 & 2 & 3 & 3 & 3 \\
\hline R2 & 4 & 3 & 3 & 3 & 3 & 2 & 3 & 3 & 4 \\
\hline R3 & 3 & 3 & 3 & 3 & 3 & 2 & 2 & 3 & 3 \\
\hline R4 & 4 & 3 & 4 & 3 & 3 & 2 & 3 & 3 & 4 \\
\hline R5 & 3 & 2 & 3 & 4 & 4 & 1 & 2 & 4 & 3 \\
\hline R6 & 3 & 2 & 3 & 3 & 3 & 1 & 2 & 3 & 3 \\
\hline R7 & 4 & 4 & 3 & 3 & 4 & 2 & 3 & 3 & 4 \\
\hline R8 & 4 & 3 & 3 & 4 & 4 & 2 & 3 & 3 & 4 \\
\hline $\mathbf{R} 9$ & 4 & 4 & 3 & 3 & 4 & 2 & 2 & 3 & 4 \\
\hline R10 & 4 & 3 & 4 & 4 & 4 & 2 & 3 & 4 & 4 \\
\hline R11 & 3 & 3 & 3 & 3 & 3 & 2 & 3 & 3 & 3 \\
\hline R12 & 4 & 3 & 3 & 3 & 3 & 2 & 3 & 3 & 4 \\
\hline R13 & 4 & 2 & 3 & 3 & 4 & 1 & 3 & 3 & 4 \\
\hline R14 & 4 & 3 & 4 & 3 & 3 & 1 & 3 & 3 & 3 \\
\hline R15 & 3 & 2 & 4 & 4 & 4 & 2 & 3 & 4 & 4 \\
\hline R16 & 4 & 3 & 3 & 3 & 3 & 1 & 2 & 4 & 3 \\
\hline R17 & 3 & 3 & 3 & 3 & 3 & 2 & 3 & 3 & 3 \\
\hline R18 & 4 & 4 & 3 & 3 & 4 & 2 & 3 & 3 & 3 \\
\hline R19 & 4 & 2 & 3 & 4 & 4 & 2 & 3 & 4 & 3 \\
\hline R20 & 3 & 3 & 3 & 3 & 3 & 1 & 3 & 3 & 3 \\
\hline
\end{tabular}

Berdasarkan rumus: Index $\%=($ Total Skor/Skor tertinggi) x 100 maka didapatkan index untuk setiap pertanyaan sebagai berikut. 
Tabel 3. Index pada tiap pertanyaan

\begin{tabular}{|l|r|r|r|r|r|r|}
\hline \multirow{2}{*}{$\begin{array}{c}\text { Nomor } \\
\text { Pertanyaan }\end{array}$} & \multicolumn{4}{|c|}{ Jumlah Responden } & & \multirow{2}{*}{$\begin{array}{c}\text { Total } \\
\text { Skor }\end{array}$} \\
\cline { 2 - 6 } & Kurang & Cukup & Baik & $\begin{array}{c}\text { Amatex } \\
\text { Baik }\end{array}$ & & \multicolumn{1}{|c|}{} \\
\hline Pertanyaan 1 & 0 & 0 & 7 & 13 & 73 & 91.25 \\
\hline Pertanyaan 2 & 0 & 5 & 12 & 3 & 58 & 72.5 \\
\hline Pertanyaan 3 & 0 & 0 & 15 & 5 & 65 & 81.25 \\
\hline Pertanyaan 4 & 0 & 0 & 15 & 5 & 65 & 81.25 \\
\hline Pertanyaan 5 & 0 & 0 & 11 & 9 & 69 & 86.25 \\
\hline Pertanyaan 6 & 6 & 14 & 0 & 0 & 34 & 42.5 \\
\hline Pertanyaan 7 & 0 & 5 & 15 & 0 & 55 & 68.75 \\
\hline Pertanyaan 8 & 0 & 0 & 15 & 5 & 65 & 81.25 \\
\hline Pertanyaan 9 & 0 & 0 & 11 & 9 & 69 & 86.25 \\
\hline
\end{tabular}

Berdasarkan nilai index untuk setiap pertanyaan dapat diketahui bahwa aplikasi mobile yang telah dikembangkan sangat membantu dalam pengaduan dan pelaporan pelanggaran reklame oleh responden. Untuk penggunaan fitur lapor, cek reklame dan peta reklame sebagian besar responden menyatakan fitur ini sangat baik. Untuk informasi reklame yang ditampilkan sebagian besar responden menunjukkan bahwa informasi yang ditampilkan sesuai dengan informasi yang diinginkan. Sementara terkait waktu yang dibutuhkan aplikasi ketika dijalankan responden menunjukkan aplikasi berjalan dalam waktu yang cukup cepat.

\section{KESIMPULAN}

Berdasarkan hasil dari penelitian ini sistem pengawasan dan pemasangan reklame dengan teknologi mobile dimana platform yang digunakan adalah android dapat disimpulkan beberapa hal, yaitu:

1) Sistem ini dapat menampilkan data reklame dengan menampilkan titik koordinat setiap lokasi reklame yang terpasang.

2) Sistem ini dapat membantu petugas dalam melakukan monitoring terhadap reklame yang terpasang.

3) Sistem ini dapat membantu petugas dan warga dalam melaporkan dan mengadukan pelanggaran reklame.
4) Dengan adanya sistem ini, diharapkan dapat membantu pimpinan untuk melihat laporan pelanggaran yang telah dilaporkan oleh petugas.

\section{SARAN}

Sistem ini masih perlu pengembangan. Adapun jadwal audit yang ada pada sistem masih dibuat secara manual. Diharapkan penjadwalan audit selanjutnya bisa dikembangnya menjadi otomatis dengan metode yang sesuai.

\section{DAFTAR PUSTAKA}

[1] Gunawan, A. Lawi, and Adnan, "Analisis Arsitektur Aplikasi Web Menggunakan Model View Controller (MVC) pada Framework Java Server Faces," Sci. J. Informatics, vol. 3, no. 1, p. 55, Jun. 2016, doi: 10.15294/sji.v3i1.5958.

[2] A. M. Gunawan, "Studi Deskriptif Tentang Efektifitas Pengawasan Perizinan Reklame di Kota Surabaya," J. Kebijak. dan Manaj. Publik, 2015.

[3] M. P. Siahaan, "Pajak daerah," J. Pajak Drh., 2009.

[4] J. Rouillard, "Contextual QR codes," 2008, doi: 10.1109/ICCGI.2008.25.

[5] K. C. Liao and W. H. Lee, "A novel user authentication scheme based on QR-code," J. Networks, 2010, doi: 10.4304/jnw.5.8.937-941.

[6] S. MUBARAQ, "Rancang Bangus Sistem Perizinan Pemasangan Reklame Berbasis Website Kabupaten Gowa (Studi Kasus Kantor Pelayanan Perizinan Terpadu)," UIN Alauddin Makassar, 2017.

[7] N. H. R. dan B. Setiyono, "Sistem Informasi Geografis Pengelolaan Reklama di Surabaya Berbasis WEB," J. Sains Dan Seni Pomits, 2013.

[8] F. Andriyastuti, "Mekanisme pengelolaan pengaduan masyarakat atas pemasangan reklame di badan penanaman modal dan pelayanan 
perizinan Kabupaten Sukoharjo," UNS, 2016.

[9] P. republik Indonesia and DPR, "Undang-Undang Republik Indonesia Nomor 28 Tahun 2009 Tentang Pajak Daerah Dan Retribusi Daerah," Indonesia, 2009. .

[10] A. Wahid and Gunawan, "View Controller Model Implementation Using Java Server Faces Framework on Uin Alauddin Makassar'S Library Web," in Proceeding Education Technology Strengthening the Learning recources fo Increasing Learners Learning, 2011, no. State University of Malang, [Online]. Available: http://digilib.unm.ac.id/files/disk1/3/ universitas negeri makassar-digilibunm-abdulwahid-118-1-prosidind.pdf. 